\title{
Chile under Pinochet
}

SIR - I have read (Nature 306, 11-12; 1983) that Chilean universities have not only survived Pinochet's dictatorship but, due to a mixture of despotic benevolence, the existence of a United Nations Regional Program for Post-Graduate Training and the quality of young scientists nurtured by their seniors, Chilean science has in fact been revived. The article exudes an aura of optimism for the future, ending with a reflective statement about the necessity for pragmatic objectives and the dismissal of "over-ambitious utopian dreams and violence".

I read the article with dismay. Certainly, history has taught me that tyrants have at times been generous patrons of the arts and conspicuous builders, but my naive heart would like to believe that tyranny kills all it touches. Furthermore, the article is disturbing because its anecdotal account of hardship fals short of picturing the excesses of Pinochet's murderous tyranny, and because the reported relaxation of the regime is hard to reconcile with reports from Amnesty International of repression, torture and assassination still rampant after 10 years of dictatorship. "Between 1973 and 1979, hundreds . . . disappeared after being arrested by the security forces ... coordinated by the Direccion de Inteligencia National (DINA). Disappearances and killings ... remain officially unexplained. Since 1977, a number of alleged members of banned political parties and organizations . . . have died in the custody of the CNI (Central National de Informaciones, Chile's secret police), in circumstances which indicate that they may have died after torture or . . . [been] killed by other means." (Political Killings by Governments, An Amnesty International Report, 20-21; 1983).

Let us put the survival issue into perspective. By the time the medical school community was taken to the soccer field, the university had already paid a grievous price - the disappearance of faculty members who were underground, exiled, or already dead. Later on, economic constraints brought the "ousting of many people and early retirements"'. The survivors were those silenced by fear and various collaborators - those people with deep-rooted rightist convictions and those pragmatic enough to accommodate their principles to the establishment. On the one hand, there was repression and on the other, compliance and consensus. How much consent is hard to evaluate, but guidelines for suppression and removal of academic personnel to be effective after the coup were clearly spelled out in a document signed by a pediatrics professor of the University of Chile.

The subject of the "open and constructive discussion" in Chilean universities which are more open and constructive than those that occur "in other countries respected for their democratic governments" is not spelled out. I must then conclude that despotism has consented not to be too despotic for people to discuss allow me to guess - the sodium pump, quantum statistics, the cost of paper clips, promotions and fund allocations. I strongly believe in academic freedom but the liberty that we are told Chilean scientists enjoy occurs simultaneously with hardship upon the Chileans that cannot be silenced nor should it be forgotten. It consists of 50 per cent unemployment in the shanty towns, it consists of the hunger of the poor, desperate citizens fighting with stones against police tear gas and bullets, people still being tortured and in prison; it consists of exiled people, it consists of the dead.

I hope that Chilean transition to democracy will occur soon and that it will be obtained without further violence. However, as long as the aims of a few are placed above the elemental rights of the enslaved many, the germ of violence will be there. The preservation of an ivory tower for a score of people cannot be the constraint to justice and equality. Justice and equality must not be utopian dreams.

ELSA BELLO-REUSS

Department of Physiology and Biophysics, Washington University School

of Medicine,

St Louis, Missouri 63110, USA

\section{Creation or evolution}

SIR - In the article "Creation versus evolution: no middle way" (Nature 305, $571-574$; 1983) George M. Marsden presents an interesting historical review of the roots of the creationism/evolution controversy in the United States, but slights its most important aspect: the science education issue. Because of pressure from antievolutionists, the amount of evolution covered in pre-college science books is documentably declining, or, even worse, is being accompanied by "theories" that the world was produced in six 24-hour days about 10,000 years ago.

There is value in Marsden's reminder that scientific creationism is more than a scientific issue. Proponents are genuinely worried that civilization and the moral order are threatened by modern antisupernaturalism. Because they define creationism narrowly, as Marsden documents, they see evolution as creationism's antithesis. Opposition to evolution thus becomes a moral charge. Textbook censors like the Gablers in Texas discourage discussions of the philosophic implications of various world views because they lead to "relativism", "humanism" and other nasty ideas. They therefore demand that creationism be presented in science, not history, social studies or philosophy classes. Unfortunately, there is no scien- tific evidence for (and much against) ideas such as obligate carnivores being former vegetarians (in order to have lived compatibly on Noah's Ark).

Whether or not evolution is "a key mythological element in a philosophy that functions as a virtual religion" (antisupernaturalism) is beside the point. Indeed, evolution can be the basis of a philosophical world view, but conceivably so can heliocentrism, or even photosynthesis. Evolution, heliocentrism and photosynthesis can be presented without philosophical trappings - it is difficult to imagine the latter two being taught otherwise. The facts are that photosynthesis occurs, the Sun is the centre of the Solar System, and change through time (evolution) has occurred. Children need and deserve to be taught this. One can be aware of the role of history and culture in science and still insist that science be taught in the science classroom.

EUGENIE C. SCOTT

Department of Epidemiology and International Health,

University of California, San Francisco, California 94143, USA

\section{Research Corporation}

SIR - Research Corporation takes exception to the article published in Nature on 13 October, 1983 (p.569) which alleges mistakes in the handling of a non-isotopic method for detecting gene sequences invented by David Ward of Yale University. That Yale did not "bungle" the technology transfer process is demonstrated by that institution's successful programme of licensing it to industry for development and commercial use.

Research Corporation, a nonprofit foundation that evaluates, patents and licenses inventions for a number of colleges and universities, was erroneously identified as having performed a review of $\mathrm{Dr}$ Ward's discovery. In fact, Yale did not submit the invention to Research Corporation, and this organization did not evaluate it or offer any opinion as to its worth.

As a further comment, and in contradiction to writer Budiansky's assertions, Yale University continues to maintain an invention administration agreement with Research Corporation, which now bases the larger part of its Invention Administration Program in Tucson, Arizona (not New York).

Research Corporation, 6840 East Broadway Boulevard, Tucson, Arizona 85710, USA

- We apologize for the error. Contrary to what was implied by Yale officials, Research Corporation did not see the original invention. Dr Schaefer is also correct in saying that an arrangement between Yale and Research Corporation continues; it is, however, non-exclusive, and Yale expects largely to assume these functions itself with the establishment of its own office - Editor, Nature. 